\title{
MANAGING SELECTION OF WIND POWER GENERATION TECHNOLOGIES
}

\author{
Andrius TAMOŠIŪNAS \\ Vilnius Gediminas Technical University, Vilnius, Lithuania \\ E-mail: andrius.tamosiunas@vgtu.lt \\ Received 02 September 2018; accepted 05 November 2018
}

\begin{abstract}
The article presents the principled model for managing the selection of wind power generation technologies enabling business organizations to transform rationally their fossil fuel-based business models towards greater renewable energy reliance. The model is aimed at complex improvement of management of the evaluation, selection processes for public and private organizations keen on switching their business models towards greater use of wind power (including (or) other renewable energy-based technologies). The set of measures proposed has a pivotal focus on the economic utility of the latter with respect to balanced and sustained strategic development of business concerned. Accordingly, the model involves tools for solving the following tasks: setting up an evaluation unit revealing critical factors for rational execution of this task; contributing to situation analysis when determining wind power generation options and assessment criteria. In this respect, besides recommendations on managing data collection, the paper also provides a spectrum of criteria for measuring the attractiveness of wind power generation technologies in terms of economic utility. The latter allow to evaluate, compare possible options in a comprehensive and complex manner; improving assessment and selection task involving and rationally utilizing multi-criteria decision analysis measures including possibilities for combination of MCDA tools if needed. In the context of empirical investigations of the evolution of wind power generation technologies in the EU and globally over the last decade, the paper reveals the benefit of the use of the proposed model specifying all its phases to relevant techniques and actions. Results of its application in practice also confirm the prevailing flexibility when adjusting the model to the specifics of activities of public and private organizations as well as of economic sectors at state, county, and municipal levels.
\end{abstract}

Keywords: wind power, multi-criteria decision, management, sustainability, business development, model.

JEL Classification: M11, M13, M21, M29.

\section{Introduction}

Dynamics of business and its environment in free market economies inevitably requires cost efficiency for any business models or actions involved in order to sustain competitiveness. The acknowledged impacts of climate change on economic systems worldwide also stipulates the need for transformation of energy systems (production, storage, supply). For instance, the European Union (EU) seek to reduce carbon dioxide $\left(\mathrm{CO}_{2}\right)$ emissions by at least $85 \%$ by 2050 compared to 1990 (e.g., other countries may have their own decarbonization targets under latest Paris Agreement (UNFCC 2016). For this purpose, the Energy Roadmap 2050 (EC 2011, 2013) tests four de-carbonization scenarios with renewables, nuclear, carbon capture and storage (CSS) and energy efficiency. Each of the scenarios in principle requires a variety of measures to be combined together into a well-matched system. Measures in question may include, for example, wind and solar, nuclear and geothermal, fossil and biofuels, hydrogen and marine energy sources as well as upgrading traditional facilities and introducing advanced information and communication technologies. However, every of given measure may have its disadvantages. It can be limited in scale, or is of unstable supply (e.g., due to erratic weather conditions) or not secure either too expensive comparing with conventional fossil fuel-based solutions. In this respect, the combination of the latter needs to be carefully considered (e.g., number of renewables or renewable with conventional solutions) inevitably involving multicriteria analysis. Respective specific scientific researches subject to matching renewable energy also other energy efficiency

Copyright $\odot 2018$ The Authors. Published by VGTU Press.

This is an Open Access article distributed under the terms of the Creative Commons Attribution License (http://creativecommons.org/licenses/by/4.0/), which permits unrestricted use, distribution, and reproduction in any medium, provided the original author and source are credited.. 
measures are limited and fragmentary. Especially the scarcity is seen when considering the application of multi-criteria analysis therein along with regard to the rationality of multifaceted management decisions involved.

Having in mind the context, the paper synthesizes a great spectrum of literature and empirical data attempting to systematically approach this issue analyzing, as the example, peculiarities of the use of wind power (on-shore and off-shore) generation solutions. The specific focus is on improving, as a complex, a management of the selection process of wind power generation technologies utilizing multi-criteria analysis tools. For this purpose, as the result of the research, the author proposes the principle management model allowing to substantiate a selection process enabling public or private organizations using the combination of the multi-criteria analysis methods to rationally choose most beneficial solutions consequently contributing to the sustained competitive growth of organization or economy (and (or) its particular sector in question) at state, county, and municipal levels accordingly.

\section{Evolving wind power generation: literature and market analysis}

The study made is built on the investigation of actual databases of relevant international public institutions (in EU, the United States (US)) along with the author's research and empirical findings made over the last 10 -year period on renewable energy solutions and carbon market development in EU.

According to the data (GWEC 2014, 2015, 2016; EWEA 2017a, 2017b), the wind power generation cumulative capacity installed has increased worldwide during the last twenty years 100 times from 2,7 gigawatts (GW) to $289 \mathrm{GW}$ by the beginning of 2013 growing annually in average by $25 \%$ between 2003 and 2013. As to the European Union (EU), the Energy Roadmap 2050 (EC 2011,2013 ) estimates $\sim 14 \%$ of EU electricity to be generated by wind power by 2020 . The investigation revealed that such progress is also affected by the technology advancement reducing energy production costs (EPC) and initial investments for wind turbines. It was noticed as well that the wind turbine electricity generators are transforming towards the permanent magnets based magnetic field (electromagnets are less reliable). The permanent magnets are more efficient at partial load and flexible than electromagnets in terms of structure, compatibility with gearboxes and other relevant electronic modules. Nevertheless, the use of permanent magnets is exposed to the following risks:

- production requires rare earth elements which are depleting while supply alternatives are limited and are subject to import constraints of the major global supplier, China;
- minerals are also radioactive therefore environmental protection rules over radioactive waste needs to be applied;

- consequently, the latter risk factors make production sensitive to price fluctuations of relevant earth elements.

For the reliability of the wind turbines a combination of the following aspects has to be considered:

- safe access to windmill (the off-(on) shore) and period of access (no of days) to the turbines especially in case of the offshore installations;

- having floating foundations is also crucial for offshore sites;

- installation time of the systems: foundations, turbine installation.

Regarding the capacity of the wind turbine the dominant range found nowadays is from 5 to $8 \mathrm{MW}$. The latter from $8 \mathrm{MW}$ are in principle offshore type due to operation noise and their physical size. For instance, diameters of the rotor for Haizhuang or Siemens turbines may reach $154 \mathrm{~m}$, Mitsubishi's - $165 \mathrm{~m}$ diameter for rotor without inverter while Samsung's turbines - $171 \mathrm{~m}$ diameter. As to observations of recent years, there are efforts towards manufacturing as more powerful as of 10MW turbines however they are not yet ready for commercial use for operating efficiency reasons.

Inevitably the acoustic noise will limit tip speed if considering onshore installation while offshore wind turbines are less constrained by the latter factor and thus may accelerate up to $80 \mathrm{~m} / \mathrm{s}$ respectively generating more electricity. Also, the greater diameter will require the heights of the hub of 80-100 meters meaning that foundations need to be capable to sustain taller towers. As to observation, while still most of the foundations are monopile type nowadays, alternatives using tribuckets, twisted jackets, suction bucket monopile, or concrete-based gravity foundations are possible. As the result, investments for foundation and its maintenance costs are to be higher. Investments for wind turbines will also depend on the following parameters:

- length of transportation of the modules;

- the soil at the site,

- the length of the connection point at the grid.

Observing investment price movement during 2006 and 2016 the global average range is of 850 EUR per kW in 2006 to 940 EUR per $\mathrm{kW}$ in 2016 (with the pick in 2007-2009 of $1200 \mathrm{EUR} / \mathrm{kW}$ worldwide (while up to $1500 \mathrm{EUR}$ per $\mathrm{kW}$ in EU) for onshore solutions. The decrease in price since 2009 (bottoming at 890 EUR per $\mathrm{kW}$ in 2013-14) is, in principle, the result of falling prices for raw materials also rising overcapacity challenges as the consequence of evolving competition (the technological progress, as mentioned earlier in this chapter, impacts the rivalry also). Of course, one should not disregard the global economic crisis blown over 2009. 
Accordingly, in such a context, the rise in the price of oil seen during 2007-2008, 2009-2014 and then since 2016 made wind power competitive (Figure 2). However, fossil fuel price dynamics since 2014 to 2016 was downward while afterwards transforming into upwards future trend correlating with inert economic growth in the United States (US) and EU, (even if to a bit lower extent in case of EU due to differences in monetary policies between EU and US; Figures 1,2) and other major economies worldwide.

If considering also Chinese manufacturers, the price could even bottom 600EUR. Respectively investments for offshore wind turbine could average by 1500 EUR per kW during 2006-2016 while reaching 4000 EUR per kW under severe offshore conditions (JRC 2015, WPD 2017, EWEA 2017a, 2017b). Analysing average annual estimated onshore operational costs, as per findings the latter amount up to 40EUR per annum under $25 \%$ capacity factor, or up to $35 \%$ of total operating expenses for onshore and offshore installations (ARUP 2011). The latter respectively correspond to the average capacity level of wind turbines, namely: for the onshore plant is 2000 full load hours when the turbine is operating in full power, and 3600 hours for offshore wind turbines. Hereby it has to be noticed that the increase in hours, even having the technological progress, is also affected by the availability of the sites (seeking for expanding the business) with potentials for operational efficiency and for perspectives of growth of electricity amount to be generated.

In this respect, nevertheless, despite the declining investment prices and reasonable operational costs, a curtailment (a forced temporary suspension of the turbine operation) as the consequence of transmission capacity limits have to be treated as a risk factor. Affecting significantly operational costs the curtailment consequently will reduce the effectiveness of the site whereas the electricity not allowed to transmit to the grid will result in the waste of the produced electricity. For instance, as to EU, a $20 \%$ increase in operational costs by 2020 is estimated if relevant regulatory rules to lessen the curtailment risk were no set (CPI 2016). Specifics of the complexity of construction modules, their installation needs to be considered as well. For instance, the onshore installation may require fewer efforts than offshore one due to the ease of access and working conditions, however additional efforts might be needed for noise mitigation along with getting no-objections for installations from local authorities, other interested parties, including households of the neighbourhood. On the other hand, offshore turbines have more hours of full load due to the longer periods of stronger winds while onshore systems will have to operate in slower motion due to geographical characteristics of the sites possible physical constraints therein. In addition to

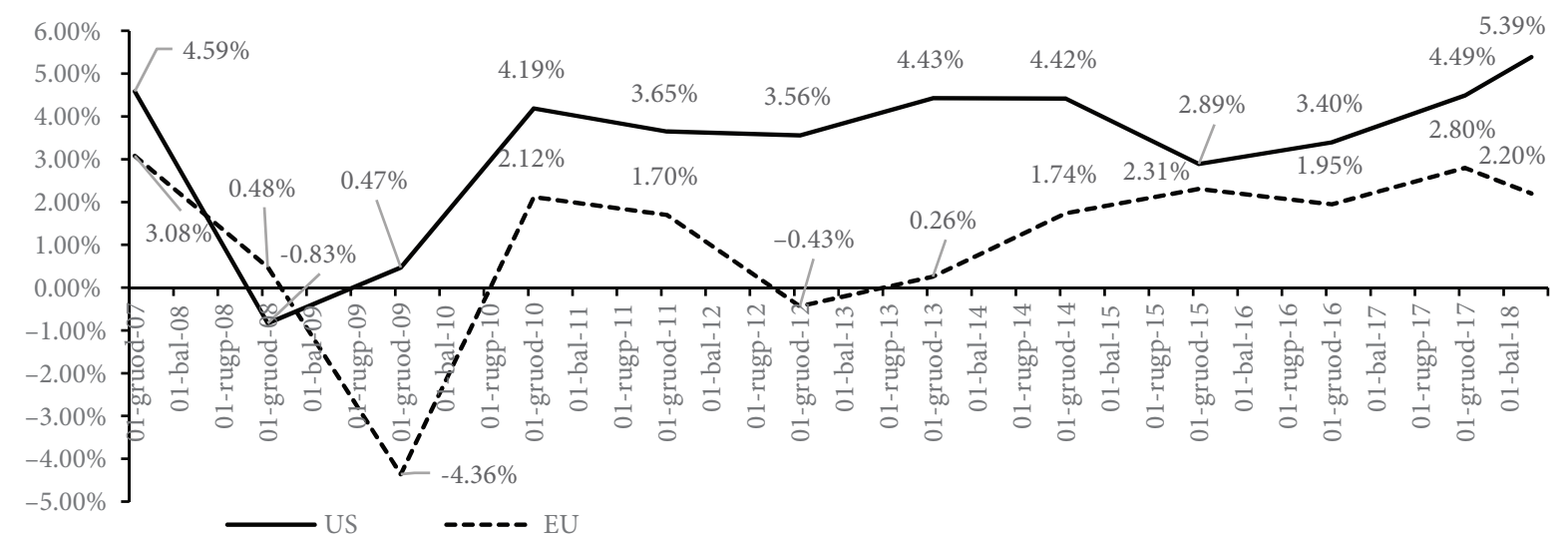

Figure 1. US and EU GDP annual growth rate from 2007-12-31 to 2018-07-20 (modified by the author, sources: Eurostat 2018, US Bureau of Economic Analysis 2018)

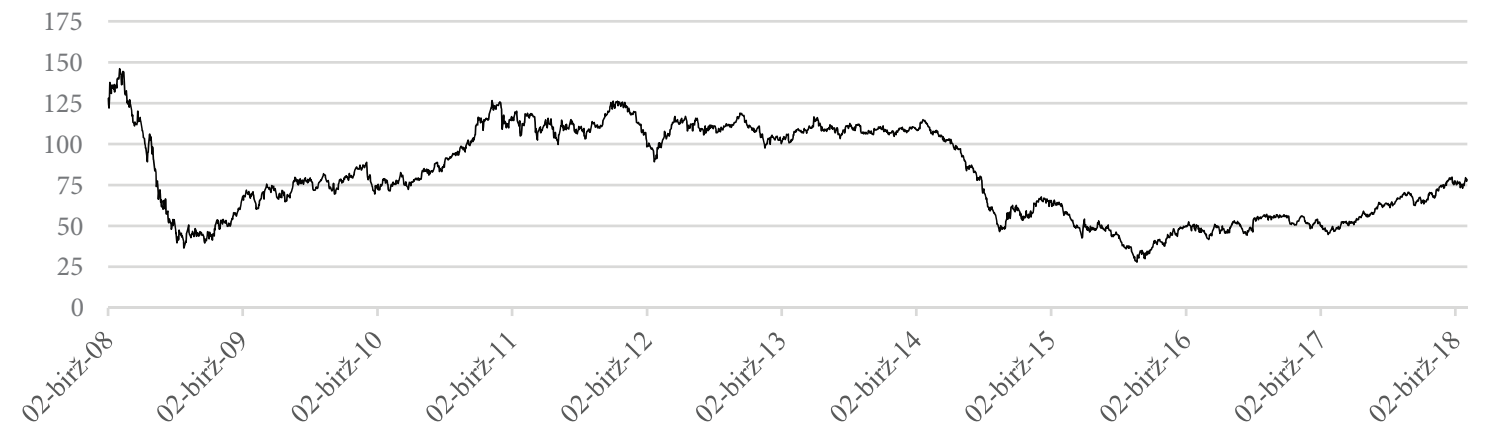

Figure 2. Oil price (EUR per barrel) dynamics from June 1 of 2008 to June 1 of 2018 (modified by the author, source: International Monetary Fund (IMF) 2018) 
the latter externalities, there are also regulatory measures aimed at enhancing cooperation among private households and market participants influencing the scope and scale of activities and hence inevitably investments and operating costs per turbine. Consequently, besides a dominant capacity range of the wind turbine (from 5 to $8 \mathrm{MW}$ ) producing the small and medium-size wind turbines (with less than $1000 \mathrm{~kW}$ capacity) is becoming a considerable feature for competitiveness. As the result, a competition among turbine producers is evolving. For example, the share of main wind turbine producers from Europe in the global market has decreased from $70 \%$ in 2008 to $42 \%$ in 2013 (JRC 2015). The stiff rivalry is also confirmed by recent data (Statista 2016, 2017a, 2017b, 2017c, 2017d, 2017e, DOE 2013, 2014, 2016, EWEA 2017a, 2017b) of the top 10 leading players in the global market (as shown in Figure 3), 5 of which are non-EU (represented by wind turbines producers of China and US).

The above analysis of evolving wind power technologies over the last decade allow to distinguish the following critical aspects:

- wind power technologies have added significant capacity;

- production costs for wind power technologies are declining;
- evaporating state financial support makes low-carbon solutions less attractive in terms of cost-effectiveness and cost-benefit results.

In addition, there is the oversupplied European Union Emissions Trading System (EU ETS) resulting in declining prices of carbon commodities (Figure 4). Hereby respectively the correlation of carbon commodities future prices is seen with GDP and Fuel Index data of Figures 1, 2. Surely the latter did not stimulate the development of low-carbon solutions until recent price increase due to stricter EC regulatory measures respectively applied to EU members.

Under such circumstances, despite provided regulatory measures mentioned above, concrete financial facilities such as European Structural and Investment Funds (ESIF) are shared relatively marginally for development of wind power and other renewable energy solutions. Observations made by the author over the last decade allow to state that the governments of EU countries preserve a traditional fossil fuel-based solutions and industries instead of stimulating the development and mass consumption of renewable energy solutions (consequently transforming in principle their economies towards the renewable fuels). Examples can be found from Lithuania, Spain or the Czech Republic when supportive regulatory measures (through either a

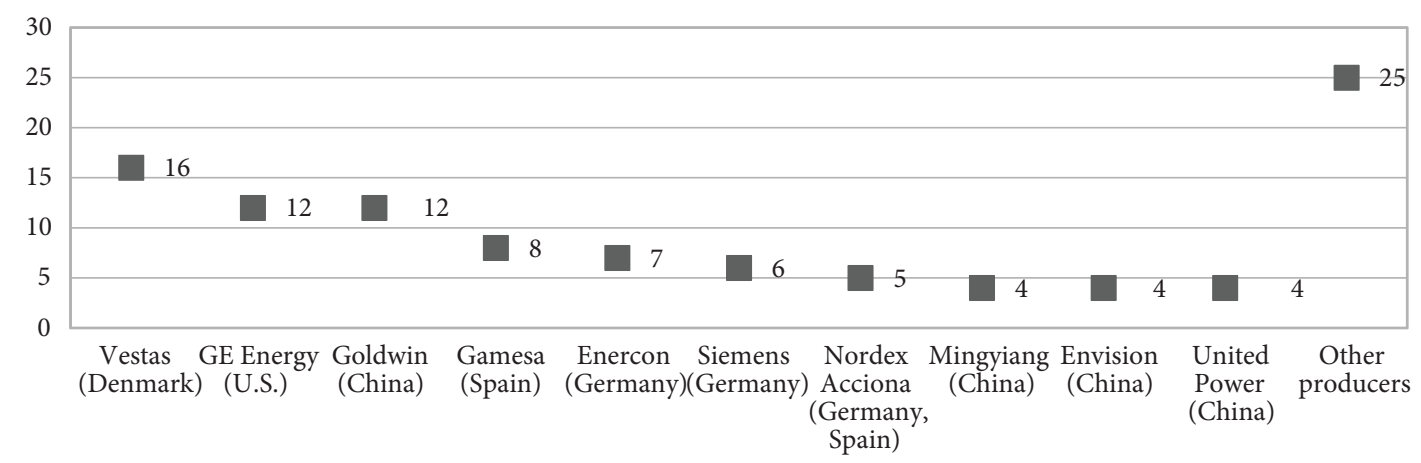

Figure 3. Global market share of 10 leading wind turbine manufacturers (modified by author, source: Statista 2016, 2017a, 2017b, 2017c, 2017d, 2017e, DOE 2013, 2014, 2016, EWEA 2017a, 2017b)

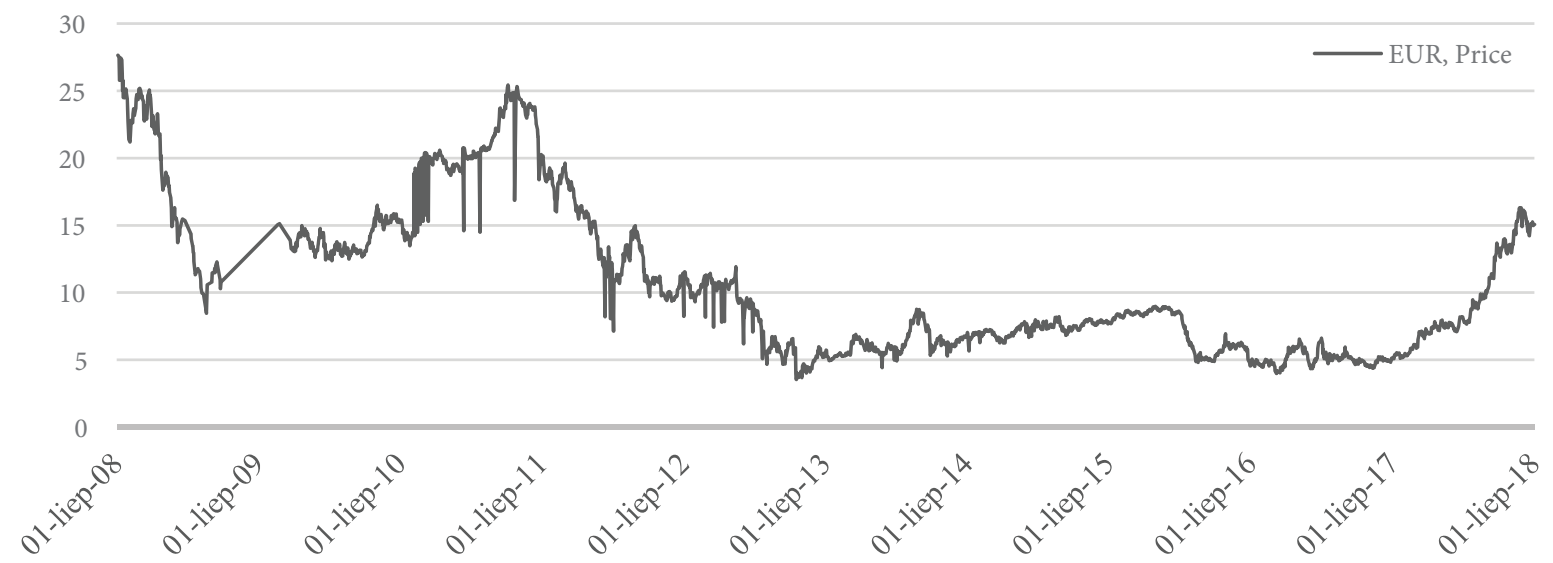

Figure 4. Carbon commodities future prices on a monthly basis from 2008-07-01 to 2018-07-01 (collected and modified by author using data from the Intercontinental Exchange (ICE), the European Energy Exchange (EEX; EEX is part of Deutsche Börse Group)) 
guaranteed feed-in tariff or a green bonus paid on top of the market price) have just been inadequate and even causing fiscal and financial, as well as other economic imbalances among industries, affected. Insufficient administrative capacity is seen also among the state and municipal governance institutions at state, regional and municipal levels. For instance, there is a lack of qualified specialists for development, installation, operation, maintenance of wind power generating solutions. Social awareness is not appropriate also. There are no concrete regulatory measures applied in order to educate, direct and assist and support (e.g., legally and (or) administratively, financially and (or) fiscally) households through the process of switching from traditional fuel based to renewable energy solutions. As to the result households do not understand comprehensively added value to be brought by the renewable fuels (e.g., wind, solar and others). Consequently, it can be challenging to select the right wind power solution for any customer, as private (business entity or household) as public (government organization (from local economies, municipalities to thematic ministries and other public interested parties).

The selection process of wind power solutions inevitably becomes impacted also by the global market dynamics, technology advancements, regulatory shifts and challenges (e.g., EU, without doubts, is a frontrunner in initiating and implementing climate change mitigating measures), as well as diffusions in the spectrum of the manufacturers and wind energy consumers (as legal entities as private households).

Such a wide and dynamic spectrum in scope and scale of factors specified above reveals the necessity for multifaceted improvement of management of the evaluation, selection processes for public and private organizations keen on switching their business models towards greater use of wind power (including (or) other renewable energy-based technologies). Organizations need solutions that would enable them to transform rationally their fossil fuel-based business models towards greater renewable energy reliance.

\section{Improving management of the selection process}

Traditionally the selection of technology (i.e., for wind power generation as per case) will be subject to investments programme (or a project) which is treated as a measure for quantitative and qualitative improvement via transforming resources into particular outcomes. However, the latter need to consider a complexity of actions, their rationality, social processes as well as shared value creation (including, as the result, the inevitable restructuring (Tamošiūnas 2017) of organizations (as private as public). The perception hereby is that the investment concerned is an open system interacting with its business environment and respectively affecting the development of the latter including its market participants (Winter et al. 2006, Winter and Szczepanek 2008, 2009).

In this context, choosing wind power generation technology is a rather challenging task whereas the latter affects the strategy of the organization in question, its business model and consequently all the interested parties involved directly or indirectly. There are several reasons for that. First of all, traditionally the decisions are in the essence made based upon the experience and information available. The latter are often fragmentary and (or) obsolete due to ongoing technology evolution as mentioned in the previous chapter. Consequently, using incomplete and outdated data do not contribute to the reliability and objectivity of the selection process (especially when considering a comprehensive quantitative assessment). Secondly, the objectivity of the choice is subject to the diversity of criteria thus the selection transforms into multiple criteria task. For instance, (as to the practical experience of the last 20 years including observations and findings of the research in question) when managing the selection process there can be up to 30 various criteria used, consisting of quantitative and qualitative ones (Hurson and Siskos 2014, Gudauskas et al. 2015). For thorough, multifaceted assessment and synthesis under this circumstance sophisticate the selection task in a methodical sense. In order to solve this task, while dealing with large amounts of diverse and dynamic data (as revealed in para 1), the decision makers, when managing the selection process, inevitably need to involve multi-criteria decision analysis (MCDA) measures.

Having the above context in mind, the subsequent chapters propose measures improving management of the selection process of wind power technologies with a pivotal focus on their utility with respect to balanced and sustained strategic development (Marková et al. 2017).

\section{The principled model for managing the selection process}

There are many MCDA techniques (eg.: AHP, COPRAS, ELECTRE, MACBETH, MULTIMOORA, PROMETHEE, REMBRANT, SMART, TOPSIS, VIKOR (Macharis et al. 2004, Opricovic and Tzeng 2004, 2007, Behzadian et al. 2010, Brito et al. 2010, Opricovic 2011, Bana e Costa et al. 2012, Corrente et al. 2014, Zolfani et al. 2014, Scholten et al. 2015, Yang et al. 2016, Masri and Houda 2016, Norese 2016, Omar and Fayek 2016) with many of their modifications. The choice of MCDA technique will depend on variability and complexity of a solution, simplicity of application of MCDA and competencies needed for proper selection, its transparency, and accountability, as well as the time limits and consistency of the overall process.

A minimum but crucial requirement for rationally managing a selection process involving the application of any MCDA technique is to set up a performance matrix. Every 
row of such matrix should be representing an option (i.e., let $O=\left\{O_{1}, O_{2}, O_{3}, \cdots, O_{m}\right\}(1)$ be, for instance, a set of $m$ investment options) and every column outlining the performance of the options against each weighted criterion (i.e., subject to $C=\left\{C_{1}, C_{2}, C_{3}, \cdots, C_{m}\right\}(2)$, a set of $n$ criteria whose weights sustaining $\left.w_{j} \in[0.1] \cdot \sum_{j=1}^{n} w_{j}=1(3)\right)$. Having in mind the revealed complexity and dynamism of the subject concerned an assessment of option performance could be as quantitative as qualitative. This challenge a compatibility of the latter thus for proper comparison a normalization of data is inevitable. The decision makers need to decide on the extent to which objectives shall be met by the entries in the performance matrix. Although processing the data can be effective and quick, nevertheless, the risk to use unjustified assumptions, affecting the ranking of options (and, as the result, a final choice) is possible.

In this respect, the analysis of data gathered and processed, findings of the research including empirical investigations on wind power generation, allow defining the principled model for managing the overall selection process (Figure 5).

In order to ensure a rationality of judgments to be made during the analysis and assessment of alternatives the model (Figure 5) encompasses the following major phases of the selection process:

- setting up an evaluation unit;

- situation analysis: determining options and criteria to assess the latter;

- evaluating the options scoring and weighting them;

- concluding on the most favourable option: analyzing the assessment results, checking their sustainability executing sensitivity analysis.

In case of disagreement on the final decision, the evaluation unit needs to repeatedly work through all the phases of the model as many times as needed in order to reach the agreement.

Each phase of the proposed model is specified in the following paragraphs.

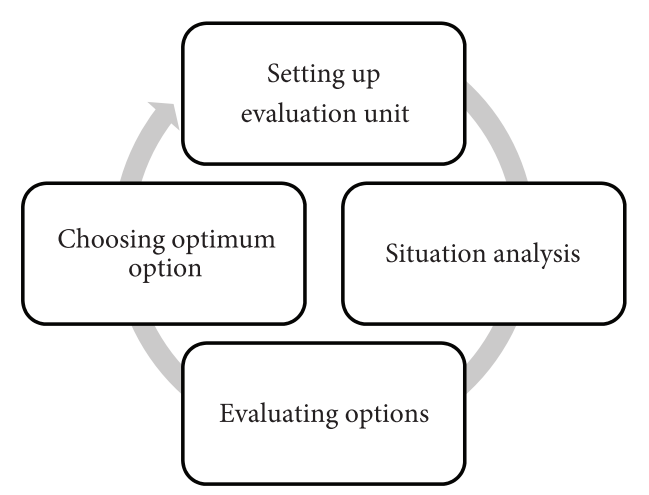

Figure 5. The principled model for managing the selection process (source: author's elaboration based on related works)

\section{Forming an evaluation unit}

The first task is subject to setting up the evaluation unit. It is recommended to form the latter of 5-9 members deciding on the eligibility of candidates by professional maturity quantified in terms number of similar and (or) directly related activities (i.e.: projects and (or) tasks) performed). As complementary criteria, a number of years of professional carrier directly related to business area concerned and respective records and references can be used as well.

In a formalized way the principle of the checking eligibility of the characteristics of the competence of potential candidates for the evaluation unit can be written as follows:

1) characteristics can be described by following unequivocal quantitative indicator:

$$
v^{p}=v^{q}
$$

where $v$ - the value of the characteristic of the candidate's competence, $p$ - candidate's competence attribute, $q$ inquiry attribute;

2) characteristics that are inquired by the least margin of the range:

$$
v^{p} \geq v_{\min }^{q}
$$

3) characteristics that are inquired by the maximum margin of the range:

$$
v^{p} \leq v_{\max }^{q}
$$

4) characteristics that are inquired by the selected minimum and maximum values:

$$
v_{\min }^{q} \leq v^{p} \leq v_{\max }^{q}
$$

Having a shortage of relevant professionals within the organization in question the external experts can be attracted (as of private as of public sector including thematic ministries and other related state organizations). In this regard, all the activities subject to the selection process have to comply, as the prerequisite, with the rules on conflict of interests' prevention.

\section{Situation analysis: determining options and assessment criteria}

In order for the evaluation unit to be capable to determine relevant options of wind power generation technologies and related solutions, respective information needs to be gathered and analyzed. Data on wind power generation can be gathered in a wide spectrum of sources. No any specific recommendations in respective literature were found for targeting expedient data sources on assessment and selection of wind power generation technologies and related solutions. Nevertheless, the use of the heuristic approach, including analogies, success stories, as well as relying on other good business practices can be reasonable when searching for proper data sources and aligning the latter using the least cost approach. 
Although the secondary information should be regarded as a priority, due to the higher costs internal data sources have to be used before the external ones. Of course, the latter choice is broad and its searching can be ranked, yet due to the high level of uncertainty, it can be difficult to justify quantitatively such prioritizations. Thus, it is sensible to use a practical experience. As per the author's experience the following sequence for searching, using the secondary sources, for appropriate data on wind power generation is proposed:

- project proposals from manufacturers and related enterprises (e.g., acting as members of the ecosystem of the latter);

- data sources of international institutions (e.g.: Eurostat, the World Bank, OECD, European Commission, United Nations);

- annual reports of a technology, related infrastructure manufacturers, designers and suppliers, maintenance service providers as well as of other related business entities;

- special and scientific literature.

- advertisements of a technology, related infrastructure manufacturers, designers, suppliers, maintenance service providers along with other related business entities;

- data from state statistics units of relevant countries;

- publicly available commercial data sources.

Nevertheless, the proposed manner can be costly thus the expediency of every search has to be justified in terms of economic benefit.

Having in mind the above context considering situation analysis it is reasonable in principle to use collective the cognitive mapping approach (Ackermann and Eden 2001). In this respect, for the example, applying the above recommendations for data collection in the selection process of wind power generation technologies in the municipality of seaside region in the context of implementation of its strategic development plan for local economies (with pivotal focus on regional electricity market liberalisation, diversification of energy resources) the following classification of technologies needs to be at least taken into consideration: high speed permanent magnets (HS-PMG), medium speed permanent magnets (MS-PMG), low speed permanent magnets (LS-PMG), hydraulic transmission (HT), high speed doubly-fed induction generator (HS-DFIG), high speed squirrel cage induction generator (HS-SCIG), low speed electromagnets (LS-EMG).

Respectively, the analysis of the application of the above technologies in practice let the evaluation unit identify the criteria to be used for assessment, comparison of options in order to ensure the rationality of the choice. As per given example (and per findings of the research presented in the previous chapter), 17 criteria (Tables 2,3 ) are determined as helpful when comparing and selecting the technologies
Table 1. Justifying values of option assessment per criterion set by the member of the evaluation unit

\begin{tabular}{|l|c|l|}
\hline $\begin{array}{c}\text { Qualitative } \\
\text { value }\end{array}$ & $\begin{array}{c}\text { Quan- } \\
\text { titative } \\
\text { value }\end{array}$ & $\begin{array}{c}\text { Example of value (maximizing and } \\
\text { minimizing) justification }\end{array}$ \\
\hline Low & 1 & $\begin{array}{l}\text { Data confirms only possibly the minor } \\
\text { positive impact of offshore facilities on } \\
\text { other local industries }\end{array}$ \\
\hline Below & 3 & $\begin{array}{l}\text { Number of operations interruption } \\
\text { events confirms the below-average } \\
\text { reliability of components }\end{array}$ \\
\hline Average & 5 & $\begin{array}{l}\text { Data confirms investments are of } \\
\text { average level }\end{array}$ \\
\hline Good & 7 & $\begin{array}{l}\text { Data confirms capacity used above } \\
\text { average level but below the higher one } \\
\text { found }\end{array}$ \\
\hline High & 9 & $\begin{array}{l}\text { Data confirms sufficient technical } \\
\text { possibilities and flexibility for grid } \\
\text { connection }\end{array}$ \\
\hline Extreme & 10 & $\begin{array}{l}\text { Data confirms a great number of cur- } \\
\text { tailment facts }\end{array}$ \\
\hline
\end{tabular}

stated above. Regarding capacity factor (CF), for maximum CF author considers Albert Betz' Limit of 59,3\% of kinetic energy. Every of 17 criteria (Tables 2,3) is weighted equally (Eq. (3)). With regard to sustained (Marková et al. 2017) and inclusive strategic development, such a distribution order is accepted as reasonable by the evaluation unit.

Whereas list of criteria consists of quantitative and qualitative ones and the data, in principle, per each of the criterion is dynamic, analysing the technologies by very criterion listed above the evaluation unit has decided to measure attractiveness of the characteristics (as per each criterion) of the technology (as to the list provided above) using the qualitative category-based approach (Table 1).

The latter decision (Table 1) can also be reasoned by exercising, for instance, with MACBETH (the Measuring Attractiveness by a Categorical Based Evaluation Technique (Bana e Costa et al. 2012) multiple criteria decision analysis method, which is, in principle, based on flexible use of qualitative indicators and (or) combination with quantitative ones accordingly (aspects of crispiness and fuzziness of data have also been under investigation by the scientists mentioned in the very first sentence of para 3).

\section{Evaluating options and selecting the optimum one}

Considering the variety of MCDA methods listed in para 3. for the assessment of wind power generation investment, the author recommends to use VIKOR MCDA method (Opricovic and Tzeng 2004, 2007, Opricovic 2011) due to the following reasons:

- the latter allows selecting feasible compromise (with possible mutual concessions) solution (even with conflicting criteria) the closest to the ideal one. 


\begin{tabular}{|c|c|c|c|c|c|c|c|c|c|c|c|c|c|c|c|c|c|}
\hline 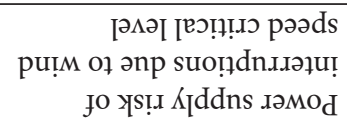 & 寻 & & $\begin{array}{l}8 \\
\vdots \\
\vdots\end{array}$ & $\begin{array}{l}8 \\
\vdots \\
\vdots\end{array}$ & $\begin{array}{l}8 \\
\vdots \\
0\end{array}$ & ڤ̂े & 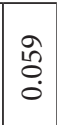 & $\begin{array}{l}\hat{\jmath} \\
\grave{0} \\
\dot{0}\end{array}$ & 容 & & $\begin{array}{l}8 \\
\vdots \\
\vdots\end{array}$ & $\begin{array}{ll}0 \\
\vdots \\
0 \\
0\end{array}$ & $\begin{array}{l}8 \\
\vdots \\
\vdots\end{array}$ & ڤે & ָे. & 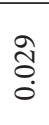 & సे \\
\hline 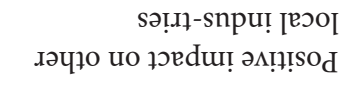 & 宏 & & $\begin{array}{l}8 \\
\vdots \\
\vdots\end{array}$ & $\begin{array}{l}8 \\
\vdots \\
0\end{array}$ & $\begin{array}{l}8 \\
0 \\
0\end{array}$ & 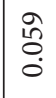 & ڤิ & ôे. & ڤે. & & $\begin{array}{l}8 \\
\vdots \\
\vdots \\
0\end{array}$ & है & $\begin{array}{l}0 \\
\vdots \\
\vdots\end{array}$ & ڤे & ڤે & ô. & ôे \\
\hline 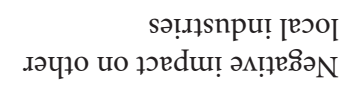 & 寻 & & $\begin{array}{l}8 \\
\vdots \\
\circ\end{array}$ & $\begin{array}{l}\stackrel{\Xi}{0} \\
\stackrel{0}{0}\end{array}$ & $\begin{array}{l}8 \\
8 \\
0\end{array}$ & 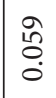 & 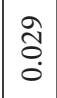 & $\begin{array}{l}\text { సे } \\
\text { ¿े }\end{array}$ & $\begin{array}{l}\text { సे } \\
\text { ¿े }\end{array}$ & & $\begin{array}{l}8 \\
\vdots \\
\vdots \\
0\end{array}$ & $\begin{array}{l}8 \\
\vdots \\
0\end{array}$ & $\begin{array}{l}8 \\
\vdots \\
\circ\end{array}$ & 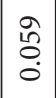 & $\begin{array}{l}8 \\
\vdots \\
\vdots\end{array}$ & $\begin{array}{l}\vdots \\
\vdots \\
\circ\end{array}$ & 官 \\
\hline 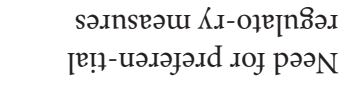 & 寻 & & $\begin{array}{l}8 \\
\vdots \\
\vdots\end{array}$ & $\begin{array}{l}\text { ले } \\
\dot{0}\end{array}$ & @ & $\begin{array}{l}\stackrel{0}{0} \\
\stackrel{0}{0}\end{array}$ & $\begin{array}{l}\hat{\tilde{b}} \\
\dot{0}\end{array}$ & $\begin{array}{l}\hat{\tilde{\sigma}} \\
\dot{0}\end{array}$ & $\begin{array}{l}\hat{\tilde{\delta}} \\
\dot{0}\end{array}$ & & $\begin{array}{l}8 \\
\vdots \\
\vdots\end{array}$ & $\begin{array}{l}8 \\
\vdots \\
\vdots\end{array}$ & $\begin{array}{l}8 \\
\vdots \\
\vdots\end{array}$ & 方 & $\begin{array}{l}\stackrel{0}{0} \\
\dot{0} \\
\dot{0}\end{array}$ & ڤั่ & ڤે \\
\hline 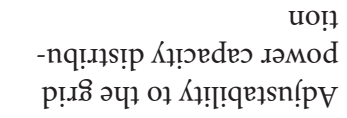 & 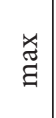 & & $\begin{array}{l}8 \\
\vdots \\
\vdots\end{array}$ & $\begin{array}{l}0 \\
\dot{0} \\
0 \\
0\end{array}$ & $\begin{array}{l}8 \\
\vdots \\
0\end{array}$ & ל̂े & $\begin{array}{l}\hat{\jmath} \\
\dot{0} \\
\dot{0}\end{array}$ & $\begin{array}{l}\text { भे } \\
\dot{0}\end{array}$ & $\begin{array}{l}\stackrel{0}{0} \\
\dot{0}\end{array}$ & & $\begin{array}{l}8 \\
\vdots \\
\vdots \\
0\end{array}$ & $\begin{array}{l}8 \\
\vdots \\
\vdots\end{array}$ & $\begin{array}{l}8 \\
\vdots \\
0 \\
0\end{array}$ & $\begin{array}{l}0 \\
\ddot{0} \\
0 \\
0\end{array}$ & 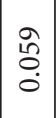 & ڤેे & ڤે \\
\hline 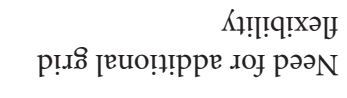 & 寻 & & $\begin{array}{l}8 \\
\vdots \\
\vdots\end{array}$ & $\underset{\hat{\sigma}}{0}$ & $\begin{array}{l}8 \\
\vdots \\
0\end{array}$ & 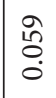 & $\underset{\hat{\sigma}}{\tilde{0}}$ & ڤิ) & 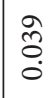 & & $\begin{array}{l}8 \\
\vdots \\
\vdots\end{array}$ & $\begin{array}{l}0 \\
\vdots \\
0 \\
0\end{array}$ & $\stackrel{8}{\vdots}$ & 命 & $\begin{array}{l}\text { fy } \\
\text { Oे } \\
0\end{array}$ & 章 & 尔 \\
\hline 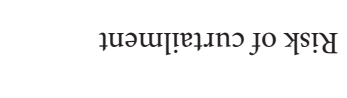 & 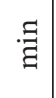 & & $\begin{array}{l}8 \\
\vdots \\
\vdots\end{array}$ & ڤે & 音 & ڤેे & $\begin{array}{l}\hat{o} \\
\dot{0}\end{array}$ & 它 & ڤे & & $\begin{array}{l}8 \\
\vdots \\
\vdots \\
0\end{array}$ & $\begin{array}{l}8 \\
\vdots \\
0\end{array}$ & $\begin{array}{l}8 \\
\vdots \\
0\end{array}$ & 方 & $\begin{array}{l}\hat{\tilde{े}} \\
\dot{0} \\
\dot{0}\end{array}$ & $\begin{array}{l}\hat{\tilde{o}} \\
\dot{0}\end{array}$ & के \\
\hline 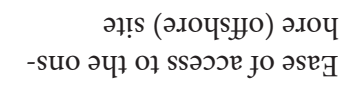 & 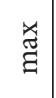 & & $\begin{array}{l}8 \\
\vdots \\
\vdots\end{array}$ & $\begin{array}{l}8 \\
\vdots \\
0 \\
0\end{array}$ & 竞 & $\begin{array}{l}8 \\
0 \\
0 \\
0\end{array}$ & $\begin{array}{l}\hat{2} \\
\hat{0} \\
0 \\
0\end{array}$ & $\begin{array}{l}\text { Iิ } \\
0 \\
0\end{array}$ & i̊ & & $\begin{array}{l}8 \\
\vdots \\
\vdots\end{array}$ & 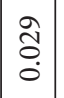 & 命 & 方 & 命 & 方 & ڤั) \\
\hline 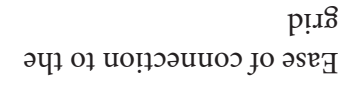 & 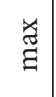 & & $\begin{array}{l}8 \\
\vdots \\
\vdots\end{array}$ & $\begin{array}{l}8 \\
\vdots \\
\vdots\end{array}$ & $\begin{array}{l}0 \\
\vdots \\
0 \\
0\end{array}$ & 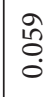 & $\begin{array}{l}8 \\
\vdots \\
\vdots\end{array}$ & $\stackrel{0}{\circ}$ & ¿. & & $\begin{array}{l}8 \\
\vdots \\
\vdots\end{array}$ & స్రి & $\begin{array}{l}8 \\
\vdots \\
\vdots\end{array}$ & 岁 & 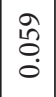 & ڤે & ڤે \\
\hline 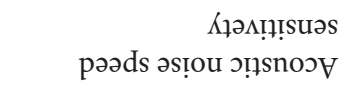 & 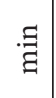 & & $\stackrel{\tilde{\sigma}}{\dot{0}}$ & $\begin{array}{l}8 \\
\vdots \\
\vdots\end{array}$ & ڤેे & ô. & $\begin{array}{l}\text { ڤે } \\
\stackrel{0}{0}\end{array}$ & $\begin{array}{l}\text { ชે } \\
\text { ô. }\end{array}$ & $\begin{array}{l}\text { भे } \\
\text { ¿े }\end{array}$ & & $\begin{array}{l}8 \\
\vdots \\
0\end{array}$ & $\begin{array}{l}a \\
0 \\
0\end{array}$ & $\begin{array}{l}8 \\
\vdots \\
0\end{array}$ & $\begin{array}{l}\hat{\jmath} \\
\hat{0} \\
0\end{array}$ & $\begin{array}{l}\overrightarrow{1} \\
\tilde{0} \\
0\end{array}$ & 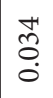 & 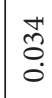 \\
\hline 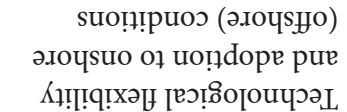 & 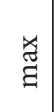 & & $\begin{array}{l}8 \\
\grave{0} \\
\circ\end{array}$ & $\begin{array}{l}0 \\
\grave{0} \\
0 \\
0\end{array}$ & $\begin{array}{l}8 \\
0 \\
0\end{array}$ & $\begin{array}{l}\hat{\jmath} \\
\text { ஸे } \\
0\end{array}$ & 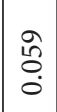 & $\begin{array}{l}\text { ชે } \\
\text { oे }\end{array}$ & $\begin{array}{l}\text { ڤે } \\
\text { o. }\end{array}$ & & $\begin{array}{l}0 \\
8 \\
0 \\
0\end{array}$ & $\mid \begin{array}{l}8 \\
\vdots \\
0\end{array}$ & $\begin{array}{l}8 \\
\vdots \\
0 \\
0\end{array}$ & \begin{tabular}{|l}
$\hat{2}$ \\
$\hat{0}$ \\
0 \\
0
\end{tabular} & $\begin{array}{l}\hat{2} \\
\hat{0} \\
0\end{array}$ & $\begin{array}{l}\hat{\partial} \\
\hat{0} \\
0\end{array}$ & 命 \\
\hline әрКכ әر!! әu!̣qnL & 孱 & & $\begin{array}{l}8 \\
\vdots \\
0\end{array}$ & $\begin{array}{l}8 \\
\vdots \\
0\end{array}$ & $\begin{array}{l}\text { ¿্రి } \\
\text { : }\end{array}$ & ôे & $\begin{array}{l}\text { ڤે } \\
\stackrel{0}{0}\end{array}$ & ôे & ڤે & & $\begin{array}{l}8 \\
\vdots \\
0\end{array}$ & $\begin{array}{l}8 \\
\vdots \\
\circ\end{array}$ & $\begin{array}{l}0 \\
0 \\
0 \\
0\end{array}$ & $\begin{array}{l}\hat{\partial} \\
\hat{0} \\
0\end{array}$ & $\begin{array}{l}\hat{\partial} \\
\text { ôे }\end{array}$ & $\begin{array}{l}\text { ชે } \\
\text { o. }\end{array}$ & ڤે \\
\hline 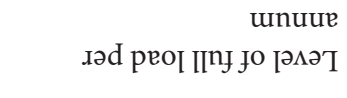 & 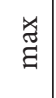 & & $\begin{array}{l}0 \\
\vdots \\
0\end{array}$ & $\begin{array}{l}\hat{\jmath} \\
\text { ठ઼. } \\
0\end{array}$ & $\begin{array}{l}8 \\
0 \\
0\end{array}$ & $\begin{array}{l}\hat{\jmath} \\
0 \\
0\end{array}$ & $\begin{array}{l}8 \\
\vdots \\
0\end{array}$ & $\begin{array}{l}\stackrel{\circ}{0} \\
\vdots\end{array}$ & $\begin{array}{l}\stackrel{\circ}{0} \\
\vdots\end{array}$ & & $\begin{array}{l}8 \\
\vdots \\
\vdots\end{array}$ & $\mid \begin{array}{c}\because \\
0 \\
0\end{array}$ & $\begin{array}{l}8 \\
\vdots \\
\vdots \\
0\end{array}$ & $\begin{array}{l}\hat{\jmath} \\
\hat{0} \\
0\end{array}$ & $\begin{array}{l}1 \\
\tilde{0} \\
0 \\
0\end{array}$ & $\begin{array}{l}n \\
\hat{n} \\
0 \\
0\end{array}$ & $\begin{array}{l}n \\
\text { ô } \\
0 \\
0\end{array}$ \\
\hline НО & 晃 & & $\begin{array}{l}8 \\
\vdots \\
0\end{array}$ & $\begin{array}{l}\stackrel{\Xi}{0} \\
\stackrel{0}{0}\end{array}$ & $\begin{array}{l}8 \\
0 \\
0\end{array}$ & $\begin{array}{l}\hat{\jmath} \\
0 \\
0\end{array}$ & $\begin{array}{l}\stackrel{\Im}{0} \\
\stackrel{0}{0}\end{array}$ & $\begin{array}{l}\text { సे } \\
\text { ठ্. }\end{array}$ & $\begin{array}{l}\text { సे } \\
\stackrel{0}{0}\end{array}$ & & $\begin{array}{l}0 \\
\vdots \\
\vdots\end{array}$ & 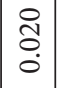 & $\begin{array}{l}0 \\
\vdots \\
0 \\
0\end{array}$ & \begin{tabular}{|l|}
$\infty$ \\
0 \\
0 \\
0
\end{tabular} & 客 & $\begin{array}{l}\text { ڤે } \\
\text { ถે }\end{array}$ & ऊ̂े \\
\hline 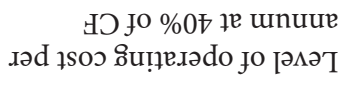 & 寻 & & $\begin{array}{l}8 \\
\vdots \\
\vdots\end{array}$ & $\begin{array}{c}\stackrel{H}{1} \\
0 \\
0\end{array}$ & 离 & $\begin{array}{l}\text { นิ } \\
\text { Oे }\end{array}$ & है. & हैं & 흥 & & @̊̀ & $\begin{array}{l}1 \\
0 \\
0\end{array}$ & $\begin{array}{l}0 \\
\vdots \\
0\end{array}$ & 䓟 & $\begin{array}{l}0 \\
\stackrel{0}{0} \\
0 \\
0\end{array}$ & 兽 & 㖞 \\
\hline рәрәәи sұuәшияәни & 寻 & : & $\begin{array}{l}8 \\
\vdots \\
0 \\
0\end{array}$ & $\begin{array}{l}\stackrel{H}{J} \\
\vdots \\
0\end{array}$ & $\begin{array}{l}8 \\
0 \\
0\end{array}$ & \begin{tabular}{l}
8 \\
\hdashline \\
0
\end{tabular} & $\begin{array}{l}\hat{o} \\
0 \\
0\end{array}$ & $\begin{array}{l}\text { ชે } \\
\text { o. }\end{array}$ & $\begin{array}{l}\text { ڤે } \\
\text { o. }\end{array}$ & : & $\begin{array}{l}8 \\
\vdots \\
0\end{array}$ & $\begin{array}{l}\stackrel{H}{H} \\
0 \\
0\end{array}$ & $\begin{array}{l}8 \\
\vdots \\
0\end{array}$ & 每 & 定 & 官 & 会 \\
\hline 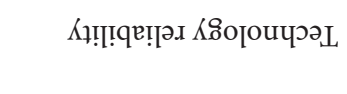 & 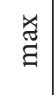 & $\begin{array}{l}\overrightarrow{\tilde{m}} \\
\dot{0} \\
\overrightarrow{0}\end{array}$ & $\begin{array}{l}8 \\
\vdots \\
\vdots\end{array}$ & $\begin{array}{l}\stackrel{\overbrace{}}{0} \\
0 \\
0\end{array}$ & 命 & $\begin{array}{l}\text { भे } \\
\text { ¿े }\end{array}$ & $\begin{array}{l}\stackrel{\leftrightarrow}{0} \\
\stackrel{0}{0}\end{array}$ & $\begin{array}{l}\text { ⿵人丶 } \\
\stackrel{0}{0}\end{array}$ & $\begin{array}{l}\text { 我 } \\
\stackrel{0}{\circ}\end{array}$ & 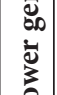 & @o & $\begin{array}{l}\stackrel{\leftrightarrow}{0} \\
0 \\
0\end{array}$ & 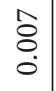 & $\begin{array}{l}\hat{2} \\
\hat{0} \\
0 \\
0\end{array}$ & 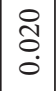 & $\stackrel{\substack{0 \\
0}}{0}$ & $\begin{array}{l}0 \\
0 \\
0 \\
0 \\
0\end{array}$ \\
\hline 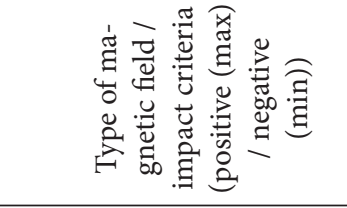 & & 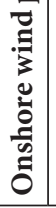 & $\begin{array}{l}0 \\
\sum_{2} \\
\dot{2} \\
\text { 至 }\end{array}$ & $\begin{array}{l}\sum_{0}^{0} \\
\sum_{1}^{\infty} \\
\sum_{i}\end{array}$ & $\sum_{\substack{1 \\
0 \\
\infty \\
\omega}}^{0}$ & 空 & \begin{tabular}{|l}
0 \\
0 \\
0 \\
0 \\
0 \\
0 \\
0
\end{tabular} & 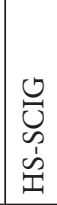 & 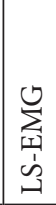 & 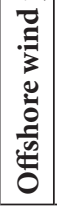 & 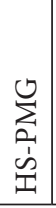 & $\begin{array}{l}0 \\
\sum_{0} \\
\sum_{1} \\
\sum\end{array}$ & 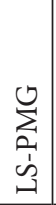 & 至 & 点 & $\begin{array}{l}0 \\
0 \\
0 \\
0 \\
0 \\
1 \\
\end{array}$ & 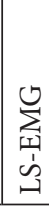 \\
\hline
\end{tabular}




\begin{tabular}{|c|c|c|c|c|c|c|c|c|c|c|c|c|c|c|c|c|c|c|c|c|c|c|c|c|c|}
\hline 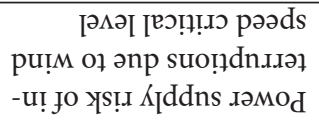 & 寻 & & $n$ & $n$ & $\wedge$ & in & in & in & in & $n$ & & 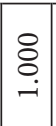 & 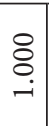 & $\begin{array}{l}8 \\
\vdots \\
\end{array}$ & $\begin{array}{l}8 \\
\vdots \\
\vdots \\
\vdots\end{array}$ & $\mid \begin{array}{l}0 \\
\vdots \\
0 \\
0\end{array}$ & $\begin{array}{l}0 \\
\vdots \\
0 \\
0\end{array}$ & ĥे & & 它 & $\hat{o}$ & :ै & $\begin{array}{l}8 \\
\vdots \\
0\end{array}$ & $\begin{array}{l}0 \\
\vdots \\
\vdots\end{array}$ & @ \\
\hline 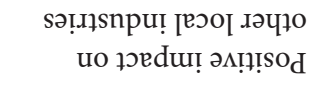 & $\stackrel{\Perp}{\sharp}$ & & $m$ & $m$ & $m$ & in & $m$ & in & in & $m$ & & 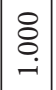 & ¿ & 京 & $\begin{array}{l}0 \\
\vdots \\
0\end{array}$ & 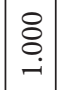 & $\begin{array}{l}0 \\
\vdots \\
0 \\
0\end{array}$ & 岂 & & $\begin{array}{l}0 \\
\hat{o} \\
0\end{array}$ & 客 & 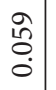 & $\begin{array}{l}8 \\
\vdots \\
0\end{array}$ & 命 & $\varliminf_{0}^{2}$ \\
\hline 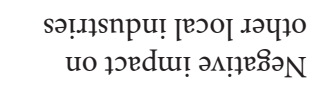 & 范 & & in & 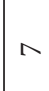 & in & $m$ & $m$ & $m$ & m & $n$ & & $\begin{array}{l}8 \\
8 \\
10 \\
0\end{array}$ & ¿ & $\mid \begin{array}{l}8 \\
0 \\
10 \\
0 \\
0\end{array}$ & ஓे & 焉 & 竞 & ל̂े & & ठે. & 官 & 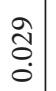 & $\begin{array}{l}\vdots \\
\vdots \\
\vdots\end{array}$ & 客 & छ \\
\hline 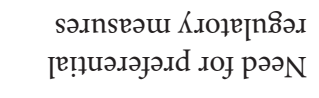 & 寻 & & $n$ & $a$ & 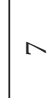 & in & in & in & in & $a$ & & $\begin{array}{l}8 \\
0 \\
0 \\
0\end{array}$ & $\stackrel{8}{\circ}$ & $\mid \begin{array}{l}8 \\
0 \\
0 \\
0\end{array}$ & $\begin{array}{l}8 \\
\vdots \\
\vdots\end{array}$ & $\mid \begin{array}{l}0 \\
\vdots \\
0 \\
0\end{array}$ & $\begin{array}{l}8 \\
\vdots \\
0 \\
0\end{array}$ & 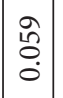 & & ָे & भे & $\begin{array}{l}\stackrel{\grave{0}}{0} \\
\dot{0}\end{array}$ & $\begin{array}{l}0 \\
\vdots \\
\vdots \\
0\end{array}$ & 官 & $\begin{array}{l}\vdots \\
\vdots \\
0\end{array}$ \\
\hline 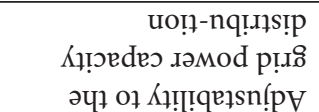 & 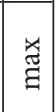 & & $a$ & $n$ & $a$ & 익 & 으 & 우 & 으 & $n$ & & $\begin{array}{c}m \\
\tilde{m} \\
0\end{array}$ & ¿ & $\begin{array}{c}m \\
\tilde{m} \\
\tilde{0}\end{array}$ & $\begin{array}{l}8 \\
\vdots \\
\vdots \\
0\end{array}$ & $\mid \begin{array}{l}0 \\
\vdots \\
0 \\
0\end{array}$ & $\begin{array}{l}8 \\
\vdots \\
0 \\
0\end{array}$ & 仝 & & 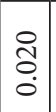 & $\mid \begin{array}{l}\hat{2} \\
\hat{0} \\
0\end{array}$ & $\begin{array}{l}\stackrel{\overbrace{}}{0} \\
\text { ¿ } \\
0\end{array}$ & 号 & ڤ్ & $\S$ \\
\hline 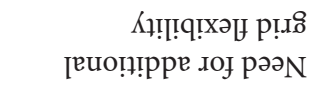 & 音 & & $n$ & $a$ & 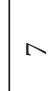 & in & in & in & in & $a$ & & $\begin{array}{l}0 \\
0 \\
10 \\
0\end{array}$ & ¿ & $\mid \begin{array}{l}8 \\
8 \\
10 \\
0 \\
0\end{array}$ & 客 & | & $\begin{array}{l}0 \\
\vdots \\
0 \\
0\end{array}$ & 总 & & సे & 客 & 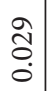 & 焉 & : & $\bigotimes_{0}^{2}$ \\
\hline 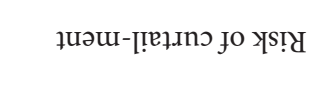 & 寻 & & $a$ & 아 $-1+1$ & $a$ & $\wedge$ & $n$ & $n$ & $n$ & 우 & & 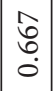 & $\underset{-}{ঃ}$ & $\mid \begin{array}{l}0 \\
0 \\
0 \\
0\end{array}$ & 号 & $\mid \begin{array}{l}0 \\
\vdots \\
0 \\
0\end{array}$ & $\begin{array}{l}8 \\
\vdots \\
0 \\
0\end{array}$ & 合 & & $\begin{array}{c}\hat{\sigma} \\
\hat{0} \\
0\end{array}$ & 岂 & 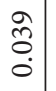 & $\bigotimes_{0}$ & $\begin{array}{l}0 \\
\vdots \\
0 \\
0\end{array}$ & 文 \\
\hline 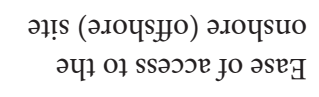 & 屋 & & $\stackrel{-}{1}$ & 으 & 으 & in & 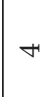 & $m$ & $\stackrel{-}{\sim}$ & $m$ & & $\begin{array}{l}8 \\
\vdots \\
0\end{array}$ & $\begin{array}{l}8 \\
\vdots \\
\vdots \\
0\end{array}$ & $\begin{array}{l}0 \\
\vdots \\
0 \\
0\end{array}$ & 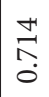 & $\mid \begin{array}{c}0 \\
0 \\
\infty \\
0 \\
0\end{array}$ & $\begin{array}{l}8 \\
\vdots \\
0 \\
-1\end{array}$ & ڤે & & $\begin{array}{l}8 \\
0 \\
0 \\
0\end{array}$ & $\begin{array}{l}8 \\
\vdots \\
0\end{array}$ & $\begin{array}{l}8 \\
\vdots \\
0\end{array}$ & $\begin{array}{l}1 \\
\text { Zै } \\
0 \\
0\end{array}$ & \begin{tabular}{l}
0 \\
\hdashline \\
0 \\
0
\end{tabular} & th \\
\hline 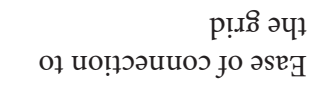 & $\stackrel{\star}{\sharp}$ & & 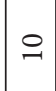 & 은 & ○ & in & t & in & 우 & H & & $\begin{array}{l}8 \\
\vdots \\
\vdots\end{array}$ & $\begin{array}{l}8 \\
\vdots \\
0\end{array}$ & 家 & $\mid \begin{array}{l}m \\
\infty \\
\infty \\
0\end{array}$ & 要 & $\left|\begin{array}{c}n \\
\infty \\
0 \\
0\end{array}\right|$ & 客 & & $\begin{array}{l}8 \\
\vdots \\
\vdots \\
\vdots\end{array}$ & 客 & $\begin{array}{ll}0 \\
\vdots \\
\vdots \\
\end{array}$ & 客 & 容 & $\begin{array}{ll}9 \\
0 \\
0\end{array}$ \\
\hline pəəds əs!̣ou & 寻 & & $a$ & $\infty$ & 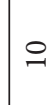 & $m$ & in & $m$ & $m$ & 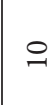 & 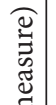 & $\mid \begin{array}{c}0 \\
0 \\
\infty \\
0 \\
0\end{array}$ & 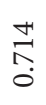 & 㐫 & 要 & $\left|\begin{array}{l}0 \\
0 \\
1 \\
0\end{array}\right|$ & $\begin{array}{ll}0 \\
\vdots \\
0 \\
0\end{array}$ & 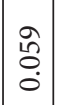 & 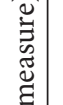 & $\begin{array}{l}0 \\
0 \\
0 \\
0 \\
0\end{array}$ & $\mid \begin{array}{l}0 \\
0 \\
0\end{array}$ & 宊 & 竞 & $\vec{a}$ & $\stackrel{8}{0}$ \\
\hline 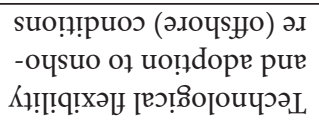 & $\stackrel{\text { }}{\sharp}$ & $=$ & $a$ & $n$ & $a$ & 은 & 우 & $\stackrel{\circ}{\circ}$ & 우 & $n$ & 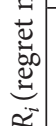 & $\mid \begin{array}{c}m \\
\tilde{m} \\
0\end{array}$ & ¿ & $\mid \begin{array}{c}\infty \\
\tilde{m} \\
0\end{array}$ & 章 & $\begin{array}{l}8 \\
8 \\
0 \\
0\end{array}$ & @ò & ôे & 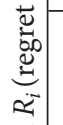 & $\begin{array}{c}\stackrel{\overbrace{}}{0} \\
0 \\
0\end{array}$ & 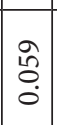 & $\begin{array}{l}\text { ते } \\
0 \\
0\end{array}$ & \begin{tabular}{|l|}
0 \\
$\vdots$ \\
0 \\
0
\end{tabular} & 京 & \& \\
\hline әрК弓 & 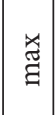 & $\hat{\imath}$ & 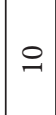 & 아 $-1+1$ & $a$ & 은 & 은 & $a$ & 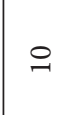 & $a$ & 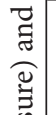 & $\begin{array}{l}0 \\
\vdots \\
0 \\
0\end{array}$ & $\begin{array}{l}8 \\
\vdots \\
0\end{array}$ & $\begin{array}{l}8 \\
\vdots \\
-i \\
-1\end{array}$ & 号 & $\begin{array}{l}8 \\
\vdots \\
0 \\
0\end{array}$ & $\begin{array}{l}8 \\
\vdots \\
-i \\
-1\end{array}$ & ôे & 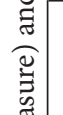 & $\begin{array}{l}8 \\
\vdots \\
0\end{array}$ & $\begin{array}{l}8 \\
\vdots \\
0\end{array}$ & 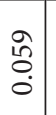 & $\begin{array}{l}8 \\
\vdots \\
0 \\
0\end{array}$ & $\begin{array}{l}8 \\
\vdots \\
0\end{array}$ & แิ \\
\hline 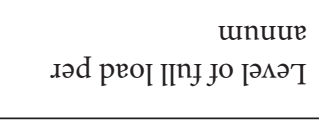 & 胥 & 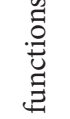 & $n$ & in & 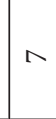 & 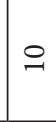 & $a$ & 은 & $\stackrel{ }{\sim}$ & in & 章 & $\begin{array}{l}8 \\
0 \\
0 \\
0\end{array}$ & $\stackrel{8}{8}$ & $\mid \begin{array}{l}0 \\
0 \\
0 \\
0\end{array}$ & 号 & 总 & $\begin{array}{l}0 \\
0 \\
0 \\
0\end{array}$ & $\mid \begin{array}{l}0 \\
\hat{o} \\
0 \\
0\end{array}$ & 绨 & $\begin{array}{l}n \\
\hat{0} \\
0 \\
0\end{array}$ & $\mid \begin{array}{l}\hat{2} \\
\ddot{0} \\
0 \\
0\end{array}$ & 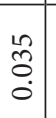 & $\begin{array}{l}8 \\
\vdots \\
0 \\
0\end{array}$ & $\begin{array}{l}1 \\
0 \\
0\end{array}$ & @ \\
\hline & 丞 & $\frac{0}{\tilde{\Xi}}$ & $a$ & $n$ & $a$ & 으 & $a$ & 은 & 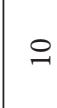 & $n$ & 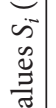 & ले & 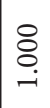 & $\mid \begin{array}{c}m \\
\tilde{m} \\
0\end{array}$ & 㝘 & 苛 & $\begin{array}{l}8 \\
0 \\
0 \\
0\end{array}$ & $\mid \begin{array}{l}0 \\
\hat{o} \\
0 \\
0\end{array}$ & 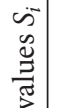 & $\begin{array}{c}0 \\
0 \\
0 \\
0\end{array}$ & भे & $\begin{array}{l}\stackrel{0}{1} \\
0 \\
0\end{array}$ & $\begin{array}{l}8 \\
\vdots \\
0 \\
0\end{array}$ & ồ & @ \\
\hline 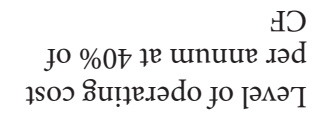 & 寻 & 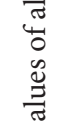 & in & 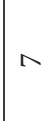 & in & $m$ & in & $m$ & m & $n$ & 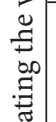 & 足 & 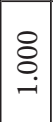 & $\mid \begin{array}{c}8 \\
8 \\
10 \\
0\end{array}$ & $\begin{array}{l}8 \\
0 \\
0 \\
0\end{array}$ & $\mid \begin{array}{l}8 \\
0 \\
0 \\
0\end{array}$ & $\begin{array}{l}8 \\
\vdots \\
0\end{array}$ & $\mid \begin{array}{l}0 \\
\hat{o} \\
0 \\
0\end{array}$ & 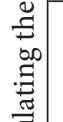 & $\begin{array}{l}\stackrel{\grave{\delta}}{\delta} \\
\dot{0}\end{array}$ & 宊 & 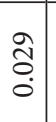 & $\begin{array}{l}8 \\
\vdots \\
0 \\
0\end{array}$ & 容 & ¿े \\
\hline 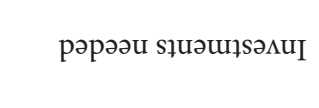 & 荞 & $\underbrace{\frac{1}{0}}_{5}$ & in & 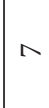 & in & in & $\wedge$ & in & in & $\wedge$ & 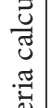 & 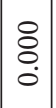 & 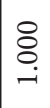 & $\begin{array}{l}8 \\
\vdots \\
0\end{array}$ & $\begin{array}{l}8 \\
\vdots \\
0\end{array}$ & \begin{tabular}{l}
8 \\
$\vdots$ \\
\hdashline \\
$-i$
\end{tabular} & $\begin{array}{l}8 \\
0 \\
0 \\
0\end{array}$ & $\mid \begin{array}{l}0 \\
\hat{o} \\
0 \\
0\end{array}$ & 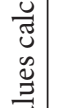 & ¿े & 官 & $\begin{array}{l}8 \\
\vdots \\
\vdots\end{array}$ & $\begin{array}{l}8 \\
0 \\
0 \\
0\end{array}$ & 命 & $\stackrel{8}{0}$ \\
\hline 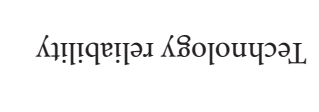 & 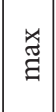 & $\begin{array}{l}\text { Ð } \\
\text { E } \\
\text { ت }\end{array}$ & 우 & 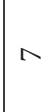 & $a$ & 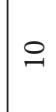 & $\wedge$ & $a$ & 은 & $n$ & 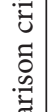 & 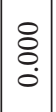 & ن. & $\mid \begin{array}{c}m \\
\tilde{m} \\
0\end{array}$ & $\begin{array}{l}8 \\
0 \\
0\end{array}$ & 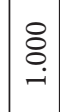 & \begin{tabular}{|c}
$n$ \\
$\tilde{n}$ \\
0
\end{tabular} & $\mid \begin{array}{l}0 \\
\hat{b} \\
0 \\
0\end{array}$ & : & $\begin{array}{l}8 \\
\vdots \\
0 \\
0\end{array}$ & $\mid \begin{array}{c}\hat{2} \\
\hat{0} \\
0 \\
0\end{array}$ & 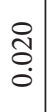 & $\begin{array}{l}8 \\
\vdots \\
0 \\
0\end{array}$ & $\begin{array}{l}\hat{o} \\
\text { ô } \\
\text { o. }\end{array}$ & ठ̊. \\
\hline 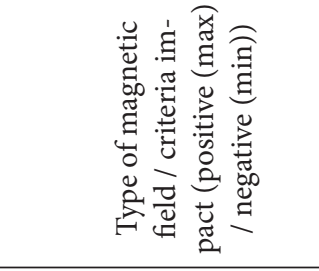 & & 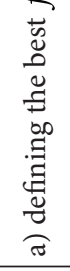 & $\mid \begin{array}{c}0 \\
0 \\
0.1 \\
01 \\
0 \\
01 \\
0 \\
0 \\
0 \\
0 \\
0 \\
0 \\
0\end{array}$ & 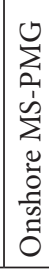 & 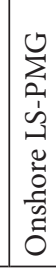 & 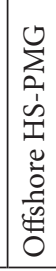 & 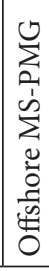 & 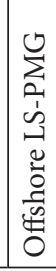 & 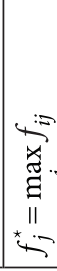 & 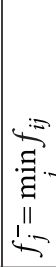 & 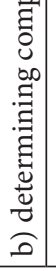 & $\begin{array}{c}0 \\
0 \\
01 \\
0 \\
0 \\
1 \\
0 \\
0 \\
0 \\
0 \\
0 \\
0 \\
0\end{array}$ & 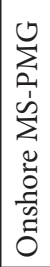 & $\mid \begin{array}{c}0 \\
2 \\
21 \\
01 \\
0 \\
0 \\
0 \\
0 \\
0 \\
0 \\
0 \\
0 \\
0\end{array}$ & 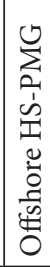 & 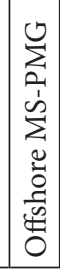 & 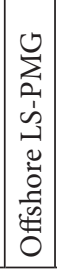 & $\mid$ & 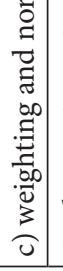 & $\mid \begin{array}{c}0 \\
\sum_{2} \\
-1 \\
0 \\
01 \\
0 \\
0 \\
0 \\
0 \\
0 \\
0\end{array}$ & 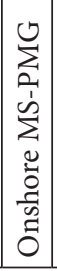 & $\begin{array}{l}0 \\
\sum_{n} \\
D_{1} \\
0 \\
0 \\
0 \\
0 \\
\bar{c} \\
0 \\
0\end{array}$ & 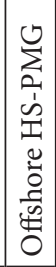 & 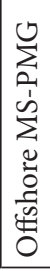 & 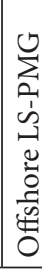 \\
\hline
\end{tabular}


- VIKOR application algorithm also tolerates further discussions, negotiations (e.g., reconsidering criteria weights), if needed, among evaluation unit members and (or) final decision makers (if the latter is the case).

There has to be noted that application of the VIKOR is based on the $L_{p}$ - metric (see Eq. (8)) as an aggregating function proposed (applying, in principle, Euclidean distance approach) by Zeleny $(2010,2011)$ :

$$
\begin{aligned}
& L_{p i}=\left\{\sum_{j=1}^{n}\left[\left(f_{j}^{*}-f_{i j}\right) /\left(f_{j}^{*}-f_{j}^{-}\right)\right]^{p}\right\}^{1 / p}, \\
& 1 \leq p \leq \infty ; \quad i=1,2,3, \ldots, m .
\end{aligned}
$$

If each option is evaluated by each criterion function, the compromise ranking under VIKOR could be performed by comparing the measure of closeness to the ideal option.

The VIKOR method exercised by the following steps (Opricovic and Tzeng, 2004, 2007, Opricovic 2011):

1 ) defining the best $f_{j}^{*}$ and the worst $f_{j}^{-}$values of all criterion functions $j=1,2, \ldots, n$. If the $j$-th function represents a benefit then:

$$
f_{j}^{*}=\max _{i} f_{i j}, f_{j}^{-}=\min _{i} f_{i j} .
$$

Executing first step (Eq. 9), as per example (of the municipality of the seaside region as mentioned above) of evaluation of power generation solutions, firstly, on the basis of identified technologies (para 5), the performance matrix was formed (see Eq.1 and 2) by the evaluation unit. In order to ensure transparency and reasonability of the process, the evaluation unit prepared performance matrixes for onshore and offshore cases defining accordingly the best and worst values for both cases.

2 ) calculating the values $S_{i}$ (utility measure) and $R_{i}$ (regret measure), $i=1,2, \ldots, m$, by these relations:

$$
\begin{aligned}
& S_{i}=\sum_{j=1}^{n} w_{j}\left(f_{j}^{*}-f_{i j}\right) /\left(f_{j}^{*}-f_{j}^{-}\right), \\
& R_{i}=\max _{j} w_{j}\left(f_{j}^{*}-f_{i j}\right) /\left(f_{j}^{*}-f_{j}^{-}\right) .
\end{aligned}
$$

Executing second step the evaluation unit, as per considered example, determined comparison criteria then weighted and normalized values (Table 2) calculating the values $S_{i}$ (utility measure) and $R_{i}$ (regret measure) respectively for onshore and offshore cases.

3 ) calculating the values $Q_{i}$ (maximum group benefits): $i=1,2, \ldots, m$, by the following relation:

$$
\begin{aligned}
& Q_{i}=v\left(S_{i}-S^{*}\right) /\left(S^{-}-S^{*}\right)+ \\
& (1-v)\left(R_{i}-R^{*}\right) /\left(R^{-}-R^{*}\right),
\end{aligned}
$$

where: $S^{*}=\min _{i} S_{i}, S^{-}=\max _{i} S_{i}, R^{*}=\min _{i} R_{i}, R^{-}=\max _{i} R_{i}$, $v$ is a weight of the strategy of "the majority of criteria" (or "the maximum utility of the group"), assuming $v=0.5$ (voting by consensus; voting "by majority rule" let $v>0.5$, or voting "with veto" means $v<0.5$ ).
4) ranking the options, sorting by values $S, R$ and $Q(S$, $R$ and $Q$ are three ranking lists accordingly calculated) in decreasing order;

5) recommending the option $O^{\prime}$ as a compromise solution, which is ranked the best by $Q$ if the following two conditions are satisfied, namely: i) of acceptable advantage when $Q\left(O^{\prime \prime}\right)-Q\left(O^{\prime}\right) \geq D Q\left(O^{\prime \prime}\right.$ is the second option in the ranking list by $Q$; and $D Q=1 /(m-1) ; m$ is the number of options); ii) of acceptable stability in decision making given that option $O^{\prime}$ is also the best ranked by $S$ or (and) $R$.

Consequently, calculations made by the evaluation unit, as per example considered (of municipality of seaside region), under steps 3, 4 and 5 allow to determine the values $S_{i}$ (utility measure), $R_{i}$ (regret measure) and the values $Q_{i}$ (maximum group benefits) for onshore and offshore case (Table 4) and, as the result, rank options.

Considering the onshore case, the best option is HSPMG with the LS-PMG, as the second best, while MS-PMG (Table 4 ) is accepted as the third one according to calculations (Table 2).

With regard to offshore solutions evaluation unit (as per considered example) has, as per calculations (Table 2), determined similar hierarchy of three best options (Table 4), however with significantly closer distances to the ideal scenario of $S_{i}$ (utility measure), $R_{i}$ (regret measure) and the values $Q_{i}$ (maximum group benefits) in principle per all options analysed (Table 4).

Table 4. Evaluation results

\begin{tabular}{|l|c|c|c|c|c|c|}
\hline $\begin{array}{c}\text { Type of } \\
\text { magnetic } \\
\text { field }\end{array}$ & $\begin{array}{c}S_{i} \\
\text { utility } \\
\text { mea- } \\
\text { sure }\end{array}$ & $\begin{array}{c}R_{i} \\
\text { regret } \\
\text { mea- } \\
\text { sure }\end{array}$ & $\begin{array}{c}\text { utility } \\
\text { mea- } \\
\text { sure } \\
\text { nor- } \\
\text { mali- } \\
\text { zed }\end{array}$ & $\begin{array}{c}R_{i} \\
\text { regret } \\
\text { mea- } \\
\text { sure } \\
\text { nor- } \\
\text { mali- } \\
\text { zed }\end{array}$ & $\begin{array}{c}Q_{i}- \\
\text { maxi- } \\
\text { mum } \\
\text { group } \\
\text { bene- } \\
\text { fits }\end{array}$ & Rank \\
\hline Onshore wind power generation solutions \\
\hline HS-PMG & 0.039 & 0.039 & 0.000 & 0.000 & 0.000 & 1 \\
\hline MS-PMG & 0.439 & 0.059 & 0.237 & 0.500 & 0.737 & 3 \\
\hline LS-PMG & 0.085 & 0.059 & 0.027 & 0.500 & 0.527 & 2 \\
\hline HT & 0.882 & 0.059 & 0.500 & 0.500 & 1.000 & 7 \\
\hline HS-DFIG & 0.745 & 0.059 & 0.419 & 0.500 & 0.919 & 6 \\
\hline HS-SCIG & 0.719 & 0.059 & 0.403 & 0.500 & 0.903 & 4 \\
\hline LS-EMG & 0.732 & 0.059 & 0.411 & 0.500 & 0.911 & 5 \\
\hline Offshore wind power generation solutions \\
\hline HS-PMG & 0.000 & 0.000 & 0.000 & 0.000 & 0.000 & 1 \\
\hline MS-PMG & 0.226 & 0.059 & 0.115 & 0.300 & 0.415 & 3 \\
\hline LS-PMG & 0.085 & 0.059 & 0.043 & 0.300 & 0.343 & 2 \\
\hline HT & 0.980 & 0.098 & 0.500 & 0.500 & 1.000 & 7 \\
\hline HS-DFIG & 0.784 & 0.059 & 0.400 & 0.300 & 0.700 & 4 \\
\hline HS-SCIG & 0.797 & 0.059 & 0.407 & 0.300 & 0.707 & 5 \\
\hline LS-EMG & 0.810 & 0.059 & 0.413 & 0.300 & 0.713 & 6 \\
\hline
\end{tabular}


Table 5. Results of comparison of the three best onshore and offshore wind power generation solutions

\begin{tabular}{|l|c|c|c|c|c|c|}
\hline $\begin{array}{c}\text { Type of } \\
\text { magnetic } \\
\text { field }\end{array}$ & $\begin{array}{c}S_{i} \\
\text { utility } \\
\text { mea- } \\
\text { sure }\end{array}$ & $\begin{array}{c}R_{i} \\
\text { regret } \\
\text { mea- } \\
\text { sure }\end{array}$ & $\begin{array}{c}S_{i} \\
\text { utility } \\
\text { mea- } \\
\text { sure } \\
\text { nor- } \\
\text { mali- } \\
\text { zed }\end{array}$ & $\begin{array}{c}R_{i} \\
\text { regret } \\
\text { mea- } \\
\text { sure } \\
\text { nor- } \\
\text { mali- } \\
\text { zed }\end{array}$ & $\begin{array}{c}Q_{i}- \\
\text { maxi- } \\
\text { mum } \\
\text { group } \\
\text { bene- } \\
\text { fits }\end{array}$ & Rank \\
\hline $\begin{array}{l}\text { Onshore } \\
\text { HS-PMG }\end{array}$ & 0.419 & 0.059 & 0.395 & 0.500 & 0.895 & 4 \\
\hline $\begin{array}{l}\text { Onshore } \\
\text { MS-PMG }\end{array}$ & 0.807 & 0.059 & 0.863 & 0.500 & 1.363 & 6 \\
\hline $\begin{array}{l}\text { Onshore } \\
\text { LS-PMG }\end{array}$ & 0.506 & 0.059 & 0.500 & 0.500 & 1.000 & 5 \\
\hline $\begin{array}{l}\text { Offshore } \\
\text { HS-PMG }\end{array}$ & 0.091 & 0.049 & 0.000 & 0.000 & 0.000 & 1 \\
\hline $\begin{array}{l}\text { Offshore } \\
\text { MS-PMG }\end{array}$ & 0.363 & 0.059 & 0.328 & 0.500 & 0.828 & 3 \\
\hline $\begin{array}{l}\text { Offshore } \\
\text { LS-PMG }\end{array}$ & 0.186 & 0.059 & 0.115 & 0.500 & 0.615 & 2 \\
\hline
\end{tabular}

Whereas according to the details of calculations (Table 2) the values for offshore solutions are reasonably better than the ones of onshore case (Table 4) the evaluation unit (as per considered example) decided to compare, using the same VIKOR methodology, the three best options of each case (detailed calculations are given accordingly in Table 3). Accordingly, the calculated values $S_{i}$ (utility measure), $R_{i}$ (regret measure) and the values $Q_{i}$ (maximum group benefits) can be ranked (Table 5).

In this respect on the basis of the calculated values $S_{i}$ (utility measure), $R_{i}$ (regret measure) and the values $Q_{i}$ (maximum group benefits) for best three onshore and offshore wind power generation technology options (Table 5) the evaluation unit (as per considered example) has accepted the offshore options to be more favourable than onshore ones with the following hierarchy: offshore HS-PMG is the best choice, offshore LS-PMG is the second best solution and offshore MS-PMG is the third best.

\section{Discussion of the results}

Considering the results of application (detailed in paragraphs 3, 4, 5 and 6) of the measures for managing the selection process of the wind power generation technologies hereby it can be stated that the proposed principled model is useful when analyzing, assessing, comparing, ranking the wind power generation technologies and deciding on the most favourable one in economic terms. Furthermore, the presented example also confirms that the proposed measures under the model (Figure 5) can be accordingly used in any subsequent public and private procurement for selection of specific offers per each of ranked technologies.
For example, under MS-PMG technology specific offers are possible from at least six producers (Areva, BARD, Gamesa, Ming Yang, Vestas, Samsung). In the case of LS-PMG concrete, offers could be expected from at least four producers (e.g.: Alstom Wind, Goldwin, Siemens, XEMS-Darwin). Consequently, the demonstrated simplicity of practical application of the model also reveals its potential for multiple uses adjusting to any particular business situation including other renewable energy solutions. Inevitably the spectrum of instruments under the model in question also allows to determine prerequisites for relevant regulatory measures and managerial potential in order to ensure sustainability of the case concerned in operational, tactical and strategic management terms. Having in mind the above context the proposed model could be valuable for the thematic ministries and municipalities, the heat and electricity producers, also water and wastewater treatment plants along with agriculture-related and other industries intensively using energy resources. Definitely, in this respect, the proposed measures may contribute when assessing the appropriateness of institutional and regulatory instruments especially in terms of stimulating the application of renewable energybased technologies as in private as in public organizations. As the result, public and private organizations can make relevant regulatory and institutional adjustments allowing to combine technologies for performance efficiency along with leading to secular and convergent economy models.

\section{Conclusions}

The market for wind power generation is evolving dynamically under constantly changing business conditions resulting in technology progress, competition, altering regulations (specific to wind power generation). In the context of such a challenging business environment the proposed principled model for managing the selection of wind power generation technologies gives the following possibilities:

- setting up an evaluation unit revealing critical factors for rational execution of this task;

- contributing to situation analysis when determining wind power generation options and assessment criteria. In this respect, besides recommendations on data collection, the paper also provides a spectrum of criteria for measuring the attractiveness of wind power generation technologies in terms of economic utility. The latter allow to evaluate, compare possible options in a comprehensive and complex manner;

- improving assessment and selection task involving and rationally utilizing MCDA measures (i.e., VIKOR MCDA method as per example provided). In this respect, the results of the practical application of VIKOR for assessing options demonstrated flexibility in the use of the proposed model and possibilities to apply other MCDA tools as well. 
The results of the paper could contribute to the inputs of further research on themes related as to wind power generation as to other renewable energy generation technologies, for instance, investigating aspects of combining the latter to the specifics of business models of public and private organizations also of economy sectors at state, county and municipal levels. Consequently, in this respect, the paper could also contribute when challenging the convergence of economic development.

\section{References}

Ackermann F, Eden C (2001) SODA - journey making and mapping in practice. In: Rosenhead J, Mingers J (Eds) Rational analysis for a problematic world revisited: problem structuring methods for complexity, uncertainty and conflict (2nd ed). Chichester: John Wiley \& Sons, 43-60.

ARUP (2011) Review of the generation costs and deployment potential of renewable electricity technologies in the UK. Report for UK DECC, 294 pp.

Bana e Costa C, De Corte J, Vansnick J (2012) MACBETH. International Journal of Information Technology and Decision Making 11 (2): 359-387. https://doi.org/10.1142/ S0219622012400068

Behzadian MRB, Albadvi KA, Aghdasi M (2010) PROMETHEE: a comprehensive literature review on methodologies and applications. European Journal of Operational Research 200 (1): 198-215. https://doi.org/10.1016/j.ejor.2009.01.021

Brito AJ, Teixeira de Almeida A, Mota CMM (2010) A multicriteria model for risk sorting of natural gas pipelines based on ELECTRE TRI integrating Utility Theory. European Journal of Operational Research 200 (3): 812-821. https:// doi.org/10.1016/j.ejor.2009.01.016

Climate Policy Initiative (CPI) (2016) Policy and investment in Germany renewable energy. CPI, $84 \mathrm{pp}$.

Corrente S, Rui Figueira J, Greco S (2014) The SMAA-PROMETHEE method. European Journal of Operational Research 239 (2): 514-522. https://doi.org/10.1016/j.ejor.2014.05.026

DOE (U.S. Department of Energy (DOE)) (2016) 2016 Wind Technologies Market Report. Lawrence Berkeley national laboratory, 2017, $82 \mathrm{pp}$.

DOE (2014) 2013 Wind Technologies Market Report. Lawrence Berkeley national laboratory, 2014, $82 \mathrm{pp}$.

DOE (2013) 2012 Wind Technologies Market Report. Lawrence Berkeley national laboratory, 2013, 80 pp.

European Commission (EC) (2011) The Energy Roadmap 2050. (COM (2011)885/2), 24 pp.

Eurostat 2018 News Release: Euro Indicators. Eurostat Press Office, 168/2018 - 30 October 2018. 2 p.

EC (2013) Conclusions on multiannual financial framework. No EUCO 37/13, 48 pp.

European Wind Energy Association (EWEA) (2017a) Financing and investments trends. The European Wind Industry in 2016. EWEA, Wind Europe, 25 pp.

EWEA (2017b) Wind in power. 2016 European statistics. EWEA, Wind Europe, $24 \mathrm{pp}$.
Gudauskas R, Kaklauskas A, Jokūbauskienè S, Targamadzė V, Budrytė L, Čerkauskas J, Kuzminskè A (2015) Advisory, negotiation and intelligent decision support system for leadership analysis. International Journal of Computers, Communications \& Control (IJCCC) 10 (5): 667-677. https:// doi.org/10.1016/j.proeng.2015.10.022

Global Wind Energy Council (GWEC) (2016) Global Wind Energy Outlook. Global Wind Energy Council. GWEC, 44 pp.

GWEC (2015) Global wind report - annual market update 2015. GWEC, 73 pp.

GWEC (2014) Global wind report - annual market update 2014. GWEC, 77 pp.

Hurson Ch, Siskos Y (2014) A synergy of multicriteria techniques to assess additive value models. European Journal of Operational Research 238 (2): 540-551. https://doi.org/10.1016/j. ejor.2014.03.047

International Monetary Fund (IMF) (2018) Commodity Market Monthly. June 2018, IMF, 24 pp.

Joint Research Centre (JRC) (2015) 2014 JRC wind status report. Technology, market and economic aspect of wind energy in Europe. Joint Research Centre, European Union, 92 pp.

Macharis C, Springael J, De Brucker Kl, Verbeke Al (2004) PROMETHEE and AHP: the design of operational synergies in multicriteria analysis. Strengthening PROMETHEE with ideas of AHP. European Journal of Operational Research 153 (2): 307-317. https://doi.org/10.1016/S0377-2217(03)00153-X

Marková V, Lesníková P, Kaščáková A, Vinczeová M (2017) The present status of sustainability concept implementation by businesses in selected industries in the Slovak Republik. E\&M Ekonomie a management $=\mathrm{E} \& \mathrm{M}$ Economics and Management 20 (3): 101-117. Liberec: Technická univerzita v Liberci. ISSN 1212-3609.

Masri HFBA, Houda A (2016) A recourse stochastic goal programming approach for the multi-objective stochastic vehicle routing problem. Journal of Multi-Criteria Decision Analysis 23 (1-2): 3-14. https://doi.org/10.1002/mcda.1563

Norese MF (2016) A model-based process to improve robustness in Multicriteria Decision Aiding interventions. Journal of Multi-Criteria Decision Analysis 23 (5-6): 183-196. https:// doi.org/10.1002/mcda.1597

Omar MN, Fayek AR (2016) A topsis-based approach for prioritized aggregation in multi-criteria decision-making problems. Journal of Multi-Criteria Decision Analysis 23 (5-6): 197-209. https://doi.org/10.1002/mcda.1561

Opricovic S, Tzeng G-H (2004) Compromise solution by MCDM methods: a comparative analysis of VIKOR and TOPSIS. European Journal of Operational Research 156 (2): 445-455. https://doi.org/10.1016/S0377-2217(03)00020-1

Opricovic S, Tzeng G-H (2007) Extended VIKOR method in comparison with outranking methods. European Journal of Operational Research 178 (2): 514-529. https://doi.org/10.1016/j. ejor.2006.01.020

Opricovic S (2011) Fuzzy VIKOR with an application to water resources planning. Expert Systems with Application 38 (10): 12983-12990. https://doi.org/10.1016/j.eswa.2011.04.097

Scholten L, Schuwirth N, Reichert P, Lienert J (2015) Tackling uncertainty in multi-criteria decision analysis - an application to water supply infrastructure planning. European 
Journal of Operational Research 242 (1): 243-260. https:// doi.org/10.1016/j.ejor.2014.09.044

Statista (2016) Renewable energy worldwide. Statista, 49 pp.

Statista (2017a) Offshore wind power globally. Statista, 52 pp.

Statista (2017b) Renewable energy in Europe. Statista, 114 pp.

Statista (2017c) Wind energy industry in Europe. Statista, 75 pp.

Statista (2017d) Wind power in United States. Statista, 55 pp.

Statista (2017e) Renewable energy sources in United States. Statista, $63 \mathrm{pp}$.

Tamošiūnas A (2017) The integrative management model for restructuring Small and Medium-sized Enterprises (SME). E\&M Ekonomie a management=E\&M Economics and Management 20 (3): 36-51. Liberec: Technická univerzita v Liberci. ISSN 1212-3609. https://doi.org/10.15240/tul/001/2017-3-003

The United Nations Framework Convention on Climate Change (UNFCC) (2016) Paris Agreement. 2016.11.04, 27 pp.

US Bureau of Economic Analysis (2018) News Release, 30 August 2018, 11 pp.

Wind Power Database (WPD) 2017 Wind Power Market Update 2016. Wind Power Database, April $1^{\text {st }}, 2017$. France, 31 pp.

Winter M, Andersen ES, Elvin R, Levene R (2006) Focusing on business projects as an area for future research an exploratory discussion of four different perspectives. International
Journal of Project Management 24 (8): 699-709. https://doi. org/10.1016/j.ijproman.2006.08.005

Winter M, Szczepanek T (2008) Projects and programmes as value creation processes: a new perspective and some practical implications. International Journal of Project Management 26 (1): 95-103. https://doi.org/10.1016/j.ijproman.2007.08.015

Winter M, Szczepanek T (2009) Images of Projects. Gower Publishing, 264 pp.

Yang RJ, Zou PXW, Wang J (2016) Modelling stakeholder-associated risk networks in green building projects. International Journal of Project Management 34: 66-81. https://doi. org/10.1016/j.ijproman.2015.09.010

Zeleny M (2010) Multiobjective optimization, systems design and De Novo programming. In: Zopounidis C, Pardalos PM (Eds) Handbook of Multicriteria Analysis. Berlin: Springer. https://doi.org/10.1007/978-3-540-92828-7_8

Zeleny, M (2011) Multiple criteria decision making (MCDM): from paradigm lost to paradigm regained? Journal of multicriteria decision analysis 18: 77-90. https://doi.org/10.1002/ mcda.473

Zolfani SH, Maknoon R, Zavadskas EK (2014) Multiple nash equilibriums and evaluation of strategies. New application of MCDM methods. Journal of Business Economics and Management 16 (2): 290-306. https://doi.org/10.3846/1611 1699.2014.967715 